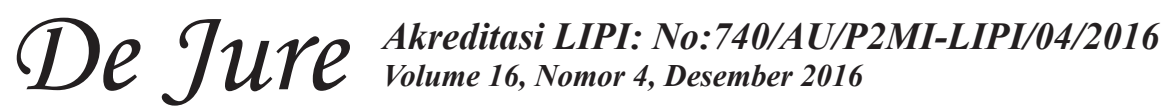

Jurnal Penelitian Hukum De Jure adalah majalah hukum triwulan (Maret, Juni, September dan Desember) diterbitkan oleh Badan Penelitian dan Pengembangan Hukum dan HAM Kementerian Hukum dan HAM RI bekerjasama dengan IKATAN PENELITI HUKUM INDONESIA (IPHI) Pengesahan Badan Hukum Perkumpulan Keputusan Menteri Hukum dan Hak Asasi Manusia Nomor : AHU-13.AHA.01.07 Tahun 2013, Tanggal 28 Januari 2013, bertujuan sebagai wadah dan media komunikasi, serta sarana untuk mempublikasikan aneka permasalahan hukum yang aktual dan terkini bagi para peneliti hukum Indonesia khususnya dan kalangan masyarakat pemerhati hukum pada umumnya.

Penanggung Jawab

Y. Ambeg Paramarta, S.H.,M.Si

(Kepala Badan Penelitian dan Pengembangan Hukum dan Hak Asasi Manusia)

\section{Pemimpin Umum}

Marulak Pardede, S.H.,M.H.,APU

(Ketua Ikatan Peneliti Hukum Indonesia)

\section{Wakil Pemimpin Umum}

T. Daniel L. Tobing, S.H

(Kepala Pusat Pengembangan Data dan Informasi Peneliti Hukum dan Hak Asasi Manusia)

DR. Agus Anwar, S.H.,M.H

(Kepala Pusat Penelitian dan Pengembangan Hukum)

Pemimpin Redaksi

Akhyar Ari Gayo, S.H.,M.H.,APU (Hukum Islam, BALITBANGKUMHAM)

\section{Anggota DewanRedaksi}

DR. Ahmad Ubbe, S.H.,M.H., APU (Hukum Adat, BALITBANGKUMHAM)

Mosgan Situmorang, S.H.,M.H (Hukum Perdata, BALITBANGKUMHAM)

Syprianus Aristieus, S.H.,M.H (Hukum Perusahaan, BALITBANGKUMHAM)

Nevey Varida Ariani, S.H.,M.H (Hukum Pidana, BALITBANGKUMHAM)

Eko Noer Kristiyanto, S.H (Hukum Perdata, BALITBANGKUMHAM)

Muhaimin, S.H (Hukum Islam, BALITBANGKUMHAM)

\section{Redaksi Pelaksana}

Yatun, S.Sos

Sekretaris

M. Virsyah Jayadilaga, S.Si.,M.P

Asmadi

\section{Tata Usaha}

Dra. Evi Djuniarti, M.H

Galuh Hadiningrum, S.H

Suwartono 


\section{TUTe $\begin{aligned} & \text { Akreditasi LIPI: No:740/AU/P2MI-LIPI/04/2016 } \\ & \text { Volume 16, Nomor 4, Desember } 2016\end{aligned}$}

Teknologi Informasi dan Desain Layout

Risma Sari, S.Kom., M.Si (Teknologi Informasi)

Machyudhie, S.T (Teknologi Infornasi)

Saefullah, S.ST.,M.Si (Teknplogi Informasi)

Agus Priyatna, S.Kom (Desain Layout)

Teddy Suryotejo

\section{Mitra Bestari}

Prof. DR. Rianto Adi, M.A (Sosilogi Hukum, UNIKA ATMAJAYA JAKARTA)

Prof. DR. Jeane Neltje Saly, S.H.,M.H (Hukum Humaniter, UNIV. 17 Agustus 1945 Jakarta)

Prof. DR. Hibnu Nugroho, S.H (Hukum Fidana, FH. UNSOED)

DR. Farhana, S.H.,M.H (Hukum Pidana, Fak. Hukum Universitas Islam Jakarta)

DR. Ridwan Nurdin, M.A (Hukum Syariah, Fakultas Syariah Univ. Arraniri Banda Aceh)

DR. Hadi Supratikta (Administrasi Pemerintahan, Balitbang Kemendagri)

\section{Alamat Redaksi:}

Gedung Badan Penelitian dan Pengembangan Hukum dan Hak Asasi Manusia

Kementerian Hukum dan Hak Asasi Manusia Republik Indonesia

Jl. HR. Rasuna Said Kav.4-5, Kuningan, Jakarta Selatan

Telepon, (021)2525015, Faksimili (021) 2526438

Email :

jurnaldejure@yahoo.com

balitbangkumham@gmail.com

ejournaldejure@gmail.com

\section{Percetakan}

PT Pohon Cahaya

Jalan Gedung Baru 18 Jakarta Barat 11440

Telpon (021) 5600111, Faksimili (021) 5670340

Redaksi menerima naskah karya asli yang aktual dalam bidang hukum berupa hasil penelitian dari berbagai kalangan, seperti: peneliti hukum, praktisi dan teoritisi, serta berbagai kalangan lainnya. Tulisan-tulisan yang dimuat merupakan pendapat pribadi penulisnya, bukan pendapat redaksi.

Redaksi berhak menolak, menyingkat naskah tulisan sepanjang tidak mengubah isinya. Naskah tulisan dapat dikirim ke alamat redaksi, maksimum 30 halaman A4, diketik spasi dua rangkap dikirim melalui Email: jurnaldejure@yahoo.com atau melalui aplikasi Open Journal System (OJS) pada URL/website: ejournalbalitbangham.go.id 


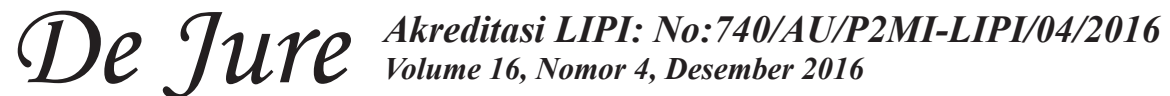

\section{DAFTAR ISI}

\section{DAFTAR ISI}

ADVERTORIAL

Perspektif Restorative Justice sebagai Wujud Perlindungan Anak yang

Bermasalah dengan Hukum

(Perspective of Restorative Justice as a ChildrenProtection

Against The Law)

$425-438$

Ulang Mangun Sosiawan

DAFTAR RIWAYAT HIDUP

$505-506$

PEDOMAN PENULISAN

507- 508 



\section{De TuPe $\begin{aligned} & \text { Akreditasi LIPI: No:740/AU/P2MI-LIPI/04/2016 } \\ & \text { Volume 16, Nomor 4, Desember } 2016\end{aligned}$}

Puji syukur kehadirat Allah SWT, Jurnal Penelitian Hukum De Jure yang diterbitkan Badan Penelitian dan Pengembangan Hukum dan HAM Kementerian Hukum dan Hak Asasi Manusia bekerjasama dengan Ikatan Peneliti Hukum Indonesia dapat menerbitkan Volume 16 Nomor 4, Desember 2016.

Para pembaca Jurnal Penelitian Hukum De Jure yang tercinta, sebagaimana diketahui bahwa pada tanggal 10 Desember setiap tahunnya diperingati sebagai Hari Hak Asasi Manusia sedunia. Tanggal ini dipilih untuk menghormat Majelis Umum PBB yang mengadopsi dan memproklamirkan Deklarasi Universal Hak Asasi Manusia, sebuah pernyataan global tentang hak asasi manusia pada 10 Desember 1948.

Apabila menilik Hukum dan HAM, merupakan konsepsi kemanusiaan dan relasi sosial yang dilahirkan dari sejarah peradaban manusia di seluruh penjuru dunia. Hukum dan HAM juga dapat dimaknai sebagai hasil perjuangan manusia untuk mempertahankan dan mencapai harkat kemanusiaannya. Agar HAM dapat ditegakkan dalam berbagai kehidupan harus ada instrumen yang mengaturnya. Instrumen tersebut berisi aturanaturan bagaimana HAM itu ditegakkan dan mengikat seluruh warganegara. Sebagai negara yang menjunjung tinggi HAM Indonesia telah memiliki setidak-tidaknya empat instrumen HAM, yakni UUD 1945, TAP MPR Nomor XVII/MPR/1998, UU Nomor 39 Tahun 1999 tentang Hak Asasi Manusia.

Dari beberapa intrumen yang ada tersebut berharap perlindungan dan penegakan HAM kedepanya dapat meningkat, karena masih banyak kekurangan-kekurangan yang harus diperbaiki oleh pemerintah. Seperti lebih difungsikan secara maksimal lembaga-lembaga yang memiliki tugas khusus menegakan HAM.

Dalam rangka memperingati Hari Hak Asasi Manusia Sedunia tersebut, Dewan Redaksi mengangkat tuisan-tulisan dari para peneliti di lingkungan Kementerian Hukum dan HAM yang bersinggungan dengan penegakan Hukum dan HAM di Indonesia.

Akhirnya kami menyampaikan ucapan terima kasih kepada Kepala Badan Penelitian dan Pengembangan Hukum dan HAM Kementerian Hukum dan HAM RI dan Ketua Ikatan Peneliti Hukum Indonesia dalam penerbitan buku ini. Dan juga kami ucapkan terima kasih kepada Prof. DR. Rianto Adi, M.A., Prof. DR. Jeane Neltje Saly, S.H.,M.H., Prof. DR. Hibnu Nugroho, S.H., DR. Farhana, S.H., M.H., DR. Ridwan Nurdin, M.A.,dan DR. Hadi Supratikta, Selaku Mitra Bestari yang telah bersedia membantu memeriksa dan mengoreksi tulisan dari para penulils.

Jakarta, Desember 2016 



\title{
PERSPEKTIF RESTORATIVE JUSTICE SEBAGAI WUJUD PERLINDUNGAN ANAK YANG BERHADAPAN DENGAN HUKUM (Perspective of Restorative Justice as a Children Protection Against The Law)
}

\author{
Ulang Mangun Sosiawan \\ Peneliti pada Pusat Penelitian dan Pengembangan Hukum, Badan Penelitian \\ dan Pengembangan Hukum dan Hak Asasi Manusia \\ Kementerian Hukum dan Hak Asasi Manusia Republik Indonesia \\ Jalan HR Rasuna Said Kavling 4-5, Jakarta Selatan 12940 \\ Telepon 021-2525015 Faksimili 021-2526438 \\ Email : ulangmangun862@gmail.com \\ Tulisan diterima: 23-08-2016;Direvisi: 28-11-2016; \\ Disetujui diterbitkan: 23-12-2016
}

\begin{abstract}
Restorative Justice is one of main approach, this time, based on the Law Number 11/2012 concerning Juvenile Justice System need to be done in the case of children against the law. This approach stresses on condition of how to create justice and balance to offenders and the victims. Mechanism, procedure and criminal justice are focused on criminalization changed into dialogue and mediation to find agreement/deal on a fair adjudication of criminal case to victims and offenders. The main problem in this research is (1) what the background of philosophy inception of restorative justice in Indonesia positive law; (2) why restorative justice has to do as children protection against the law; and (3) how to apply restorative justice in criminal justice of children protection against the law. This research uses normative and empirical juridical approach that is means or procedure used to solve the research problem by researching secondary data, previously then proceed primary data in the field. Primary data obtained by people through observation and interview. The result of this research shows that restorative justice must be done as entity of children protection against the law, because it essentially cannot remove from context that cover it, so it is not fair if he/she has retributive sanction without paying attention existence and condition surrounding him/her. The implementation of restorative justice of the Juvenile Justice System Law carried on diversion mechanism, with court product such as stipulation (articles 12 and 52, and non diversion/mediation, can be conducted outside or inside of trial, with verdicts, namely criminal or criminal action (article 69. Mechanism of dialogue and mediation is held by engaging other parties. It concludes that the practice of criminal justice, restorative justice as entity of children protection against the law has not become primary tendency, yet.
\end{abstract}

Keywords: restorative justice, protection form, and diversion

\begin{abstract}
ABSTRAK
Restorative Justice (Keadilan Berbasis Musyawarah) adalah satu pendekatan utama, yang saat ini, berdasarkan Undang-undang Nomor 11 Tahun 2012 tentang Sistem Peradilan Pidana Anak, wajib dilakukan dalam perkara anak yang berhadapan dengan hukum. Pendekatan ini lebih menitikberatkan pada kondisi terciptanya keadilan dan keseimbangan bagi pelaku tindak pidana serta korbannya sendiri. Mekanisme tata cara dan peradilan pidana yang berfokus pada pemidanaan diubah menjadi proses dialog dan mediasi untuik menciptakan kesepakatan atas penyelesaian perkara pidana yang lebih adil dan seimbang bagi pihak korban dan pelaku. Pokok permasalahan dalam penelitian ini adalah (1) Apa latar belakang filosofis lahirnya Restorative Justice dalam UU SPPA? (2) Mengapa Restorative Justice harus dilakukan sebagai perlindungan terhadap anak yang berhadapan dengan hukum; dan (3) Bagaimana cara menerapkan Restorative Justice dalam praktik peradilan pidana sebagai perlindungan anak yang berhadapan dengan hukum. Metode pendekatan yang dipergunakan dalam penelitian ini adalah yuridis normatif dan empiris, yaitu cara atau prosedur yang digunakan untuk memecahkan masalah penelitian dengan meneliti data sekunder terlebih dahulu untuk kemudian dilanjutkan dengan meneliti data primer yang ada di lapangan. Data primer adalah data yang diperoleh langsung dari masyarakat. Hasil
\end{abstract}


penelitian menunjukkan bahwa Restorative Justice harus dilakukan sebagai wujud perlindungan atas anak yang berhadapan dengan hukum, karena pada dasarnya ia tidak dapat dilepaskan dari konteks yang melingkupinya, sehingga tidak adil apabila ia dikenai sanksi retributif, tanpa memperhatikan keberadaannya dan kondisi yang melingkupinya. Implementasi Restorative Justice dalam UU Sistem Peradilan Pidana Anak adalah dilakukan melalui mekanisme Diversi, dengan produk pengadilan berupa penetapan (Pasal 12 dan 52, dan non diversi/ mediasi, yang bisa dilakukan di luar atau di dalam persidangan, dengan produk pengadilan berupa putusan, yaitu pidana atau tindakan (Pasal 69). Mekanisme dialog dan mediasi dilangsungkan dengan melibatkan selain kedua belah pihak pelaku dan korban, dapat juga pihak lain. Berdasarkan kesimpulan hasil penelitian dalam praktek peradilan pidana, penerapan Restorative Justice sebagai wujud perlindungan hak anak yang berhadapan dengan hukum belum menjadi kecenderungan utama.

Kata Kunci: Restorative Justice, Bentuk Perlindungan, dan Diversi.

\section{PENDAHULUAN}

Restorative Justice saat ini telah menjadi istilah yang tren dan populer, khususnya di kalangan akademisi, penegak hukum dan praktisi hukum sebagai sebuah paradigma atau pendekatan pemidanaan dalam menangani tindak pidana atau kejahatan, baik yang dilakukan oleh anak-anak maupun orang dewasa. Sebagai sebuah paradigma atau pendekatan pemidanaan, Restorative Justice diharapkan menjadi salah satu cara atau alternatif penanganan tindak pidana atau kejahatan yang lebih mengedepankan pemulihan keseimbangan hubungan antara pelaku tindak pidana dan korban.

Kejahatan yang dilakukan oleh anak pada dasarnya tidak lepas dari berbagai tekanan hidup, baik ekonomi dan sosial. Anak yang kurang atau tidak mendapat perhatian secara fisik, mental maupun sosial seringkali berperilaku dan bertindak anti sosial yang merugikan dirinya sendiri, keluarga, dan masyarakat (Nashriana, 2011:76). Akibatnya tidak sedikit anak-anak yang menjadi pelaku tindak pidana atau kejahatan.

Terdapat beragam sebutan untuk anak yang melanggar norma yang hidup dalam masyarakat dan melakukan tindak pidana. Diantaranya, pertama, sebutan anak nakal, sebagaimana dalam UU No. 3 Tahun 1997 tentang Pengadilan Anak. Kedua, anak yang bermasalah dengan hukum, sebagaimana digunakan dalam UU No. 23 Tahun 2002 tentang Perlindungan Anak, Ketiga anak dalam situasi khusus (children in need of special protetion/CNSP), sebagaimana dalam Konvensi Hak Anak/KHA (Conevention The Right of The Childrens/CRC, Keempat, dalam perspektif UNICEF disebut, Children in specialy difficult circumtances (CDEC). Ini karena kebutuhankebutuhan anak itu yang tidak terpenuhi, sehingga rentan mengalami tindak kekerasan, berada di luar lingkungan keluarga (berada pada lingkup otoritas institusi negara), membutuhkan proteksi berupa regulasi khusus, membutuhkan perlindungan dan kemauan diri. Kebutuhan-kebutuhan ini tidak dapat dipenuhi karena anak tersebut tidak mendapatkan perlindungan dan perawatan yang layak dari orang dewasa yang berada di lingkungan tempat di mana biasanya anak menjalani hidup (Joni, 2012:5).

Untuk itu, perspektif Restorative Justice penting dikedepankan dalam menangani problematika kejahatan anak. Argumentasinya adalah bahwa Restorative Justice dapat ditawarkan sebagai suatu pendekatan dan penyelesaian utama, yang dianggap mampu memenuhi tuntutan pemidanaan yang berorientasi pada sesuatu hal yang menguntungkan bagi semua pihak. Pendekatan Restorative Justice merupakan suatu paradigma yang dapat dipakai sebagai bingkai dari strategi penanganan perkara pidana yang bertujuan menjawab ketidakpuasan bekerjanya sistem peradilan pidana yang ada saat ini (Zulfa, 2011:63).

Peradilan pidana yang ada sekarang saat ini masih mengalami kelemahan, karena posisi korban dan masyarakat yang belum mendapatkan posisinya sehingga kepentingan keduanya menjadi terabaikan. Pendapat demikian, misalnya dikemukakan (Rizvietha, 2012/11/27). Asas inquisitoir ini sesuai dengan pandangan bahwa pengakuan tersangka merupakan alat bukti terpenting. Dasar hukum asas inquisitoir terdapat pada Pasal 164 HIR: "Maka yang disebut bukti, yaitu: bukti surat bukti, saksi, sangka, pengakuan dan sumpah.Sedangkan asas accusatoir adalah kebebasan memberi dan mendapatkan penasehat hukum menunjukkan bahwa KUHAP telah menganut sistim akusator, walaupun dalam dalam pekatek masiah ada pelanggaran maka disebut 


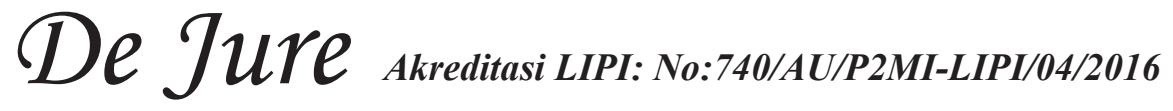

accusatoir belum penuh, yang berarti perbedaan antara pemeriksaan pendahuluan dan pemeriksaan sidang pengadilan pada mdasarnya telah dihilangkan. jaminan serta pelindungan terhadap hak asasi tersangka dan terdakwa belum memadai, artinya sering terjadi pelanggaran hak asasi dalam bentuk kekerasan dan penyiksaan pada tahap pemeriksaan penyiidkan tidak ada jaminan

Berdasarkan latar belakang masalah di atas, permasalahan penegakan hukum terhadap kejahatan anak dengan menggunakan Persepktif Restorative Justice menarik dan penting untuk diteliti lebih mendalam. Menarik dan Penting diteliti karena pendekatan Restorative Justice menjadi kecenderungan yang digunakan dalam sistem peradilan pidana saat ini, yang secara jelas diatur dalam sistem perundang-undangan pidana anak yang baru, yaitu UU No. 11 Tahun 2012 (UU SPPA).

Permasalahan yang akan diangkat dari tulisan ini adalah (1) Apa latar belakang filosofis lahirnya Restorative Justice dalam UUSPPA?;

(2) Mengapa Restorative Justice harus dilakukan sebagai perlindungan terhadap anak yang berhadapan dengan hukum?; (3) Bagaimana cara menerapkan Restorative Justice dalam praktik peradilan pidana sebagai perlindungan anak yang berhadapan dengan hukum?

\section{METODE PENELITIAN}

Penelitian ini merupakan suatu penelitian yuridis normatif dan yuridis empiris sekaligus (Soekanto, 1986:43). Dengan sumber bahan hukum primer, sekunder, dan tersierdan sumber data sekunder yang diperoleh dengan studi dokumentasi, sedangkan untuk menganalisisnya digunakan metode interaktif. Teori yang digunakan sebagai pisau analisis untuk mengelaborasi permasalahan yang diangkat antara lain teori restorative justice, teori diversi, teori perlindungan HAM, teori perlindungan anak, hukum sebagai cerminan dari masyarakat.

\section{PEMBAHASAN}

Argumen Filosofis, Yuridis dan Penerapan Perspektif Restorative Justice sebagai wujud perlindungan Anak Yang Berhadapan dengan Hukum.

\section{Argumen Filosofis}

Argumen filosofis yang mendasari pentingnya penerapan perspektif Restorative Justice sebagai wujud perlindungan hak anak yang berhadapan dengan hukum berpijak pada 3 (tiga) teori utama, yaitu teori Groundnorm, Welfare State, dan Hukum Progresif. Sebagaimana telah dikemukakan bahwa dalam kehidupan bangsa Indonesia, Pancasila adalah dasar negara. Pada masa lalu Pancasila cenderung digunakan sebagai alat legitimasi kekuasaan dan lebih menjadi ideologi tertutup. Dikarenakan adanya pendapat bahwa Pancasila berada di atas dan di luar konstitusi. Pancasila disebut sebagai norma fundamental negara (Staatfundamentalnorm) dengan menggunakan teori Hans Kelsen dan Hans Nawiasky.

Dalam konteks pemerapan Restorative Justice, teori hukum Progresif relevan dijadikan argumentasi filosofis. Berdasarkan teori Hukum Progresif, penegakan hukum terhadap kejahatn anak harus dimaksudkan untuk tercapainya keadilan, dalam pengertian keseimbangan antara keadilan bagi korban dan keadilan bagi pelaku. Berdasarkan teori hukum progresifini, Hakim dapat dan bahkan harus menrobos ketentuan perundangundangan (UUSPPA) mengenai kewajiban untuk menerapkan pendekatan Restorative Justice, Dengan cara ini, keadilan yang merupakan citacita hukum dapat dirasakan oleh para pihak dalam perkara pidana anak.

\section{Argumen Yuridis}

Negara Indonesia adalah negara hukum. Salah satu tolok ukur negara hukum adalah adanya peraturan perundang-undangan. Dalam konteks perlindungan hukum bagi anak yang berhadapan dengan hukum terdapat beberapa undang-undang, yang pada dasarnya bertujuan untuk kebaiakan si anak.

(a) UU RI Nomor 35 Tahun 2014 Tentang Perubahan Atas UU Nomor 23 Tahun 2002 tentang Perlindungan Anak Pasal 64 Ayat (2);

"Perlindungan khusus bagi anak yang berhadapan dengan hukum sebagai mana dimaksud dalam ayat (1) dilaksanakan melalui:

a. Perlakuan atas anak secara manusiawi sesuai dengan martabat dan hak-hak anak; 
b. Penyediaan petugas pendamping khusus anak sejak dini;

c. Penyediaan sarana dan prasarana khusus;

d. Penjatihan sanksi yang tepat untuk kepentingan yang terbaik bagi anak;

e. Pemantauan dan pencatatan terus menerus terhadap perkembangan anak yang berkonflik dengan hukum;

f. Pemberian jaminan untuk mempertahankan hubungan dengan orang tua atau keluarga, dan

g. Perlindungan dari pemberitaan identitas melalui media massa dan untuk menghindari labelisasi.

(b) UU RI Nomor 11 Tahun 2012 Tentang Sistem Peradilan Pidana Anak dalam Pasal 5 Ayat (1) yang berbunyi: Sistem Peradilan Pidana Anak wajib mengutamakan pendekatan Keadilan Restorataive.”. Dalam Pasal 2 UU SPPA ini secara jelas disebutkan bahwa:

"Sistem Peradilan Pidana Anak dilaksanakan berdasarkan asas:

a. Perlindungan;

b. Keadilan

c. Nondiskriminasi;

d. Kepentingan terbaik bagi Anak;

e. Penghargaaan terhadap pendapat Anak;

f. Kelangsungan hidup dan tumbuh kembang Anak;

g. Pembinaan dan pembimbingan Anak;

h. Proporsional

i Perampasan lemerdekaan mdan pemidanaan sebagai upaya terakhir, dan

j. Penghindaran pembalasan.

Pasal-pasal yang menopang Pasal 5 di atas misalnya Pasal 3 dan 4 yang menegaskan mengenai hak-hak Anak.

Pasal 3

Setiap Anak dalam proses peradilan pidana berhak:

a. Diperlakukan secara manusiawi dengah memperhatikan kebutuhan sesuai dengan umurnya;

b. Dipisahkan dari orang dewasa; c. Memperoleh bantuan hukum dan bantuan lain secara efektif;

d. Melakukan kegiatan rekreasional;

e. Bebas dari penyiksaan, penghukuman atau perlakuan lain yang kejam, tidak manusiawi, serta merencahkan derajat dan martabatnya;

f. Tidak dijatuhi pidana mati atau pidana seumur hidup;

g. Tidak ditangkap, ditahan atau dipenjara, kecuali sebagai upaya terakhir dan dalam waktu yang paling singkat;

h. Memeproleh keadilan di muka pengadilan anak yang obyektif, tidak memihak, dan dalam sidang yang tertutup untuk umum;

i. Tidak dipublikasikan identitasnya;

j. Memperoleh pendampingan orang tua/ Wali dan orang yang dipercaya oleh Aak;

k. Memperoleh advokasi sosial;

1. Memperoleh kehidupan pribadi;

m. Memperoleh aksesibilitas, teritama bagi anak cacat;

n. Memperoleh pendidikan;

o. Memperoleh pelayanan kesehatan; dan

p. Memperoleh hak lain sesuai dengan ketentuan peraturan perundangundangan.

Adapun Pasal 4 UU SPPA berbunyi sebagai berikut:

(1) Anak yang sedang menjalani masa pidana berhak:

a. Mendapat pengurangan masa pidana;

b. Memperoleh asimilasi;

c. Memperoleh cuti mengunjungi keluarga;

d. Memperoleh pembebasan bersyarat;

e. Memperoleh cuti menjelang bebas;

f. Memperoleh cuti bersyarat; dan

g. Memperoleh hak lain sesuai dengan ketentuan peraturan perundangundangan.

(2) Hak sebagaimana dimaksud pada ayat (1) diberikan kepada Anak yang memenuhi persyaratan sebagaimana diatur dalam ketentuan peraturan perundang-undangan. 


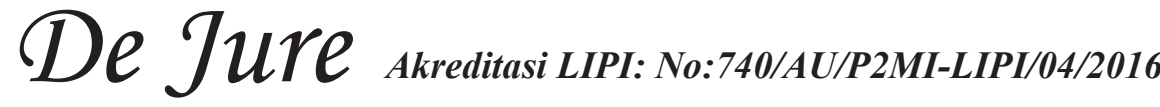

Sungguhpun demikian jika mengacu kepada beberapaundang-undang diatas, tentupenyelesaian hukum terhadap anak yang berhadapan dengan hukum haruslah berpijak pada ketentuan hukum yang lebih memberikan keadiloan baginya.

\section{Penerapan Restorataive Justice}

Implementasi Restorative Justice dalam UU Sistem Peradilan Pidana Anak adalah dilakukan melalui mekanisme Diversi, dengan produk pengadilan berupa penetapan (Pasal 12 dan 52, dan non diversi/mediasi, yang bisa dilakukan di luar atau di dalam persidangan, dengan produk pengadilan berupa putusan, yaitu pidana atau tindakan (Pasal 69). Mekanisme dialog dan mediasi dilangsungkan dengan melibatkan selain kedua belah pihak pelaku dan korban, dapat juga pihak lain. Berdasarkan kesimpulan hasil penelitian dalam praktek peradilan pidana, penerapan Restorative Justice sebagai wujud perlindungan hak anak yang berhadapan dengan hukum belum menjadi kecenderungan utama.

Terdapat banyak variasi bentuk pendekatan yang digunakan dalam penerapan Restorative Justice. Secara umum model-model tersebut, sebagaimana dipaparkan oleh (Zulfa, 2011:8892), dapat dikelompokan menjadi 3 (tiga) bentuk utama yang dikenal, sebagai berikut:

(1) Victim offender mediation adalah salah satu bentuk pendekatan restoratif, di mana dibuat suatu forum yang mendorong pertemuan antara pelaku dan korban yang dibantu oleh mediator sebagai koordinator dan fasilitator dalam pertemuan tersebut. Bentuk ini dirancang untuk mencari kebutuhan yang menjadi prioritas korban, khususnya kebutuhan untuk didengar keinginan-keinginannya mengenai: a) bentuk tanggungjawab pelaku; b) kebutuhan akan pengobatan atau pendampingan bagi korban; dan c) keinginan korban untuk didengarkan pelaku terhadap dampak tindak pidana bagi kedua pihak dan berdiskusi tentang penanganan, usaha perbaikan dari dampak yang diderita oleh keduanya.

(2) Adapun conferencing adalah bentuk penerapan pendekatan Restorative Justice yang dikembangkan di New Zealand, dan merupakan reaksi dari proses penyelesaian perkara pidana secara tradisional yang ada di suku Maori, penduduk asli bangsa Negara tersebut. Bentuk ini kemudian diadopsi oleh banyak Negara seperti Australia, Afrika Selatan, Amerika Serikat dan beberapa Negara Eropa. Dalam bentuk conferencing ini penyelesaian perkara bukan hanya melibatkan pelaku dan korban langsung (primary victim), tetapi juga korban secara tidak langsung (secondary victim) seperti keluarga atau kawan dekat korban serta keluarga dan kawan dekat pelaku. Dari beberapa model conferencing yang berkembang, model yang disebut Family Group Conference(FCG) menjadi model yang berkembang terkait dengan penanganan perkara tindak pidana yang dilakukan oleh anak. Dalam model ini penyelesaian akhir difokuskan pada upaya pemberian pelajaran atau pendidikan kepada pelaku atas perbuatannya terhadap korban.

(3) circles adalah bentuk penerapan Restorative Justiceyang diadopsi dari praktek di Kanada, di mana para pihak yang terlibat meliputi pelaku, korban, keluarga, dan pihak lain yang terlibat termasuk di dalamnyapenegakhukum. Berbeda dengan dua model sebelumnya, dalam model ini, setiap anggota masyarakat yang merasa berkepentingan dengan perkara tersebut dapat datang dan ikut berpartisipasi. Dalam hal ini, Circles didefinisikan sebagai pihak-pihak yang berkepentingan dengan tindak pidana secara meluas.

\section{ANALISIS.}

Analisis Konsep Restorative Justice Terhadap Perlindungan anak yang berhadapan dengan hukum berdasarkan UU No. 11 Tahun 2012 Tentang Sistem Peradilan Pidana Anak

\section{A. Latar belakang filosofis lahirnya Restorative Justice}

Anak adalah bagian yang tidak terpisahkan dari keberlangsungan hidup manusia dan keberlangsungan sebuah bangsa dan negara. Dalam konstitusi Indonesia anak memiliki peran strategis yang secara tegas dinyatakan bahwa negara menjamin hak setiap anak atas kelangsungan hidup, tumbuh, dan berkembang serta atas perlndungan dari kekerasan dan diskriminasi. Oleh karena itu, kepentingan terbaik bagi anak patut dihayati sebagai kepentingan terbaik bagi kelangsungan hidup umat manusia.

Adapun substansi yang diatur dalam undangundang ini, antara lain, mengenai penempatan 
Anak yang menjalani proses peradilan dapat ditempatkan di Lembaga Pembinaan Khusus Anak (LPKA). Substansi yang mendasar dalam undang-undang ini adalah pengaturan secara tegas mengenai keadilan Restorative dan Diversiyang dimaksudkan untuk menghindari dan menjauhkan Anak dari proses peradilan sehingga dapat menghindari stigmatisasi terhadap anak yang bermasalah dengan hukum dan diharapkan Anak dapat kembali ke dalam lingkungan sosial secara wajar. Oleh karena itu, sangat diperlukan peran serta semua pihak dalam rangka mewujudkan hal tersebut.

Proses itu harus bertujuan pada terciptanya Keadilan restorative, baik bagi Anak maupun bagi Korban. Keadilan Restoratif merupakan suatu proses Diversi, yaitu semua pihak yang terlibat dalam suatu tindak pidana tetentu bersamasama mengatasi masalah serta menciptakan satu kewajiban untuk membuat segala sesuatunya menjadi lebih baik dengan melibatan korban, Anak, dan masyarakat dalam mencari solusi untuk memperbaiki, rekonsiliasi, dan menentramkan hati yang tidak berdasarkan pembalasan.

Dari kasus yang muncul, ada kalanya Anak berada dalam status saksi dan/atau korban sehingga Anak Korban dan/atau Anak Saksi juga diatur dalam undang-undang ini. Khusus mengenai sanksi terhadap Anak ditentukan berdasarkan perbedaan umur Anak, yaitu telah mencapai umur 12 (dua belas) tahun sampai dengan 18 (delapan belas) tahun dapat dijatuhi tindakan dan pidana.

Mengingat ciri dan sifat yang khas pada anak dan demi perlindungan terhadap Anak, perkara anak yang berhadapan dengan hukum wajib disidangkan di pengadilan pidana anak yang berada di lingkungan peradilan umum. Proses peradilan perkara Anak sejak ditangkap, ditahan, dan diadili pembinaannya wajib dilakukan oleh pejabat khusus yang memahami masalah anak. Namun, sebelum masuk proses peradilan, para penegak hukum, keluarga, dan masyarakat wajib mengupayakan proses penyelesaian di luar jalur pengadilan, yakni melakukan Diversi berdasarkan pendekatan Keadilan Restoratif.

Undang-Undang Sistem Peradilan Pidana Anak ini mengatur mengenai keseluruhan proses penyelesaian perkara anak yang berhadapan dengan hukum mulai tahap penyelidikan sampai dengan tahap pembimbingan setelah menjalani pidana.

\section{B. Landasan Yuridis}

Landasan yuridis Restorative Justice dalam UU SPPA, sebagaimana landasan hukum yang digunakan dalam pembentukan undang-undang ini, yaitu: (a) Pasal 5 Ayat (1), Pasal 20, Pasal 28B Ayat (2), Pasal 28G ; dan Pasal 281 UUD 1945; (b) UU No. 39 Tahun 1999 tentang HAM (LN RI Tahun 1999 No. 165, TLN RINo. 3886); (c) UU No. 35 Tahun 2014 tentang Perlindungan Anak.; (d) UU No. 13 Tahun 2006 tentang Perlindungan Saksi dan Korban (LN RI Tahun 2006 No. 64, TLN RI No. 4635); (e) UU No. 16 Tahun 2011 tentang Bantuan Hukum (LN I Tahun 2011 No. 104, TLN No. 5248).

\section{Implementasi Restorative Justice Berdasarkan Undang-Undang sistem Peradilan Anak.}

\section{Restorative Justice di Luar Pengadilan}

\section{a. Mekanisme Melalui Diversi}

Dalam Pasal 1 Angka 5 disebutkan: "Diversi adalah pengalihan peyelesaian perkara Anak dari proses peradilan pidana ke proses di luar peradilan pidana."Adapun tujuan diversi adalah untuk: (1) mencapai perdamaian antara korban dan Anak; (2) menyelesaikan perkara Anak di luar proses peradilan; (3) menghindarkan Anak dari perampasan kemerdekaan; (4) mendorong masyarakat untuk berpartisipasi; dan (5) menanamkan rasa tanggung jawab kepada Anak. Tujuan Diversi di atas, sebagaimana disebutkan dalam Bab II Pasal 6, yang berbunyi sebagai berikut:Diversi bertujuan: a. mencapai perdamaian antara korban dan anak; b. menyelesaikan perkara Anak di luar proses peradilan; c. menghindarkan Anak dari perampasan kemerdekaan; d. mendorong masyarakat untuk berpartisipasi; dan e. menanamkan rasa tanggung jawab kepada Anak.

Ketentuan mengenai kewajiban melakukan diversi diatur dalam Pasal 7. Pasal 7 (1) Pada tingkat penyidikan, penuntutan, dan pemeriksaan perkara Anak di pengadilan negeri wajib diuoayakan Diversi. (2) Diversi sebagaimana dimaksud pada ayat (1) dilaksanakan dalam hal tindak pidana yang dilakukan: a. diancam dengan pidana penjara di bawah 7 (tujuh) tahun; dan b. bukan merupakan pengulangan tindak pidana. Adapun tatacara proses diversi itu diatur dalam pasal 8 sebagai berikut. 


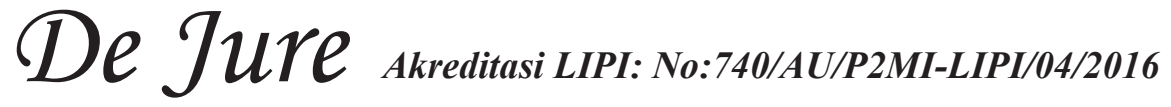

Pasal 8 (1) Proses Diversi dilakukan melalui musyawarah dengan melibatkan Anak dan orang tua/Walinya, korban dan/atau oran tua/Walinya. Pembimbing Kemasyarakatan, dan pekerja sosial profesonal berdasarkan pendekatan Keadilan Restoratif. (2) Dalam hal diperlukan, musyawarah tenaga kesejahteraan sosial, dan/atau masyarakat.

Berdasarkan Pasal 8 angka (3) di atas jelas bahwa dalam prose diversi wajib diperhatikan 6 (enam) aspek yaitu: kepentingan korban; kesejahteraan dan tanggung jawab anak; penghindaran stigma negatif; pengindaran pembalasan; keharmonisan masyarakat; dan kepattan, kesusilaan, dan ketertiban umum. Selanjutnya, dalam Pasal 9 ayat (1) diatas mengenai hal-hal yang harus dijadikan pertimbangan oleh Penyidik, Penuntut Umum, dan Hakim dalam melakukan Diversi. Hal-hal dimaksud mencakup: kategori tindak mpidana; umur anak; hasil penelitian kemasyarakatan dari Bapas; dan dukungan lingkungan keluarga dan masyarakat.

Pasal 9 (1) Penyidik, penunutut Umum, dan haim dalam melaksanakan Diversi harus mempertimbangkan:a. Kategori tindak pidana; $b$. Umur anak; c. Hasil penelitian kemasyarakatan dari bapak; dan d. Dukungan lingkungan keluarga dan masyarakat. Selain itu, dalam hal kesepakatan di versi harus ada persetujuan korban dan/atau kelurga korban serta kesediaan anak dan keluarganya, kecuali untuk beberapa hal, sebagaimana disebutkan dalam pasal 9 Ayar (2) berikut: (2) Kesepakatan Diversi harus mendapatkan persetujuan korban dan/atau keluarga Anak Korban serta kesediaan Anak dan keluarganya, kecuali, untuk: a. tindak pidana yang berupa pelanggaran; $b$. Tindak pidana tingan; $c$. Tindak pidana tanpa korban; atau d. Nilai kerugian korban tidak lebih dari nilai upah minimum provinsi setempat.

Adapun mengenai ketentuan kesepakatan diversi untuk menyelesaikan tindak pidana yang berupa pelanggaran, tindak pidana ringan, tindak idana tanpa korban, atau nilai kerugia korban tidak lebih dari upah minimum provinsi, diatur dalam Pasal 10.

Pasal 10. (1) Kesepakatan diversi untuk menyelesaikan tindak pidana yang berupa pelanggaran, tindak pidana ringan, tindak pidana tanpa korban, atau nilai kerugian korban tidak lebih dari upah minimum provinsi, setempat sebagaimana dimaksud dalam pasal 9 ayat (2) dapat dilakukan oleh penyidik bersama pelaku dan/atau keluarganya pembimbing kemasyarakatan, serta dapat melibatkan tokoh masyarakat.

Kesepakatan diversi tersebut dapat berbentuk pengembalian kerugian dalam hal ada korban: rehabilitas medis dan psikososial; penyerahan kembali kepada orang tua/wali; ke-ikut sertaan dalam pendidikan atau pelatihan di lembaga pendidikan aatau LPKS paling lama 3 (tiga) bulan; atau pelayanan masyarakat paling lama 3 (tiga) bulan. Hal demikian, sebagaimana disebutkan dala Pasal 10 ayat (2):

Kesepakatan diversi sebagaimana dimaksud pada ayat (1) dilakukan oleh Pendidik atas rekomendasi Pembimbing Kemasyarakatan dapat berbentuk: a. pengembalian kerugian dalam hal ada korban: b. rehabilitas medis dan psikososial; c. penyerahan kembali kepada orang tua/wali; d. keikutsertaan dalam pendidikan atau pelatihan di lembaga pendidikan aatau LPKS paling lama 3 (tiga) bulan; atau e. pelayanan masyarakat paling lama 3 (tiga) bulan.

Pasal 11 berbunyi: Hasil kesepakatan Diversi dapat berbentuk, antara lain: a. Perdamaian dengan atau tanpa ganti kerugian; b. Penyerahan kembali kepada orang tua/Wali; c. Keikutsertaan dalam pendidikan atau pelatihan di lembaga Pendidikan atau LPKS paling lama 3 (tiga) bulan; atau $d$. Pelayanan masyarakat.

Selanjutnya, hasil kesepakatan diversi dituangkan dalam bentuk kesepakatan Diversi, yang disampaikan oleh atasan langsung pejabat yang bertanggungjawab di setiap tingkat pemeriksaan ke pengadilan negeri sesuai dengan daerah hukumnya dalam waktu paling lama 3 (tiga) hari sejak kesepakatan dicapai untuk memperoleh penetapan. Penetapan ini dilakukan dalam waktu paling lama 3 (tiga) hari terhitung sejak diterimanya kesepakatan Diversi. Penetapan itu kemudian disampaikan kepada Pembimbing Kemasyarakatan, penyidik, Penuntut Umum, atau Hakim dalam waktu paling lama 3 (tiga) hari sejak ditetapkan. Selanjutnya setelah menerima penetapan tersebut, Penyidik menerbitkan penetapan penghentian penyidikan atau Penuntut Umum menerbitkan pengetapan penghentian penuntutan, Prosedur kesepakatan Diversi hingga penetapan demikian, disebutkan dalam pasal 12 Ayat (1) s/d (5): 
Pasal 12 (1) Hasil kesepakatan sebagaimana dimaksud dalam pasal 11 dituangkan dalam bentuk Diversi; (2)Hasil kesepakatan Diversisebagaimana dimaksud pada ayat (1) disampaikan oleh atasan langsung peabat yang bertanggungjawab di setiap tingkat pemeriksaan ke pengadilan negeri sesuai dengan daerah hukumnya dalam waktu paling lama 3 (tiga) hari sejak kesepakatan dicapai untuk memperoleh penetapan. (3) Penetapan sebagaimana dimaksud pada ayat (2) dilakukan dalam paling lama 3 (tiga) hari terhitung sejak diterimanya kesepakatan Diversi (4) Penetapan sebagaimana dimaksud pada ayat (3) disampaikan kepada Pembimbing Kemasyarakatan, penyidik, Penuntut Umum, atau Hakim dalam waktu paling lama 3 (tiga) hari sejak ditetapkan. (5) Setelah menerima penetapan sebagaiamna dimaksud pada ayat (4), Penyidik menerbitkan penetapan penghentian penyidikan atau Penuntut Umum menerbitkan pengetapan penghentian penuntutan.

Demikian ini disebutkan dalam pasal 13 berikut: Proses peradilan pidana Anak dilanjutkan dalam hal: a. proses Diversi tidak menghasilkan kesepakatan; b. kesepakatan Diversi itu tidak dilaksanakan. Tahapan selanjutnya, dalam proses diversi dan pelaksanaan kesepakatan diversi itu adalah pengawasan Demikian ini disebutkan dalam Pasal 14 Ayat (1): "Pengawasan atas proses Diversi dan pelaksanaan kesepakatan yang dihasilkan berada pada atasan langsung pejabat yang bertanggung jawab di setiap tingkat pemeriksaan." Terkait Dengan proses Diversi sampai dengan kesepakatan Diversi dilaksanakan terdapat ketentuan yang wajib dilakukan oleh pembimbing Kemasyarakatan, yaitu melakkan pendampingan, pembimbngan, dan pengawasan.

Ketentuan ini disebutkan dalam Pasal 14 Ayat (2): (1) Selama proses Diversi berlangsung sampai dengan kesepakatan Diversi dilaksanakan, pembimbing Kemasyarakatan wajib melakukan pendampingan, pembimbing, dan pengawasan. Selanjutnya, tugas Pembimbing Kemasyarakatan itu adalah melaporkan kepada pejabat yang bertanggung jawab ketika kesepakatan Diversi tidak dilaksanakan dalam waktu yang ditentukan. Selanjutnya laporan itu wajib di tindaklanjuti oleh pejabat tersebut dalam waktu paling lama 7 (tujuh) hari.

Selanjutnya, mengenai ketentuan mengenai pedoman pelaksanaan proses Diversi, tata cara, dan koordinasi pelaksanaan Diversi diatur dengan
Peraturan pemerintah. Hal ini sebagaimana disebutkan dalam pasal 15: "Ketentuan mengenai pedoman pelaksanaan proses Diversi, tatacara, dan koordinasi pelaksanaan Diversi diatur dengan Peraturan pemerintah."'Hingga penelitian ini dilakukan belum diterbitkan Peraturan Pemerintah yang mengatur mengenai pedoman pelaksanaan proses Diversi, tatacara, dan koordinasi pelaksanaan Diversi.

\section{b. Bentuk Putusan}

Bentuk putusan pengadilan ketika tercapai kesepakatan Diversi adalah penetapan. Penetapan ini dilakukan paling lama 3 (tiga) hari terhitung setelahditerimanyakesepakatanDiversi.Penetapan ini kemudian disampaikan kepada Pembimbing kemasyarakatan, penyidik, penuntut Umum, atau hakim dalam waktu paling lama 3 (tiga) hari sejak ditetapkan. Setelah menerima penetapan tersebut Penyidik menerbitkan penetapan penghentian penyidikan atau penuntut Umum menerbitkan penetapan penghentian penuntutan. Hal ini sebagaimana diatur dalam pasal 12 Ayat (2) sampai dengan ayat (5), sebagai berikut:

Pasal 12. (1) Hasil kesepakatan Diversi sebagaiamna dimaksud pada yat (1) disampaikan oleh atasan angsung pejabat yang bertanggung jawab di setiap tingkat pemeriksaan ke pengadilan negeiri sesuai dengan daerah hukumnya dalam waktu paling lama 3 (tiga) hari sejak kesepakatan dicapai untuk memperoleh penetapan. (2) Penetapan sebagaimana dimaksud pada ayat (2) dilakukan dalam waktu paling lama 3 (tiga) hari Terhitung sejak diterimanya kesepakatan Diversi; (3) Penetapan sebagaimana dimaksud pada ayat (3) disampaikan kepada Pembimbing kemasyarakatan, penyidik, penuntut Umum, atau hakim dalam waktu paling lama 3 (tiga) hari sejak ditetapkan. (4) Setelah menerima penetapan sebagaimana dimaksud pada ayat (4), Penyidik menerbitkan penetapan penghentian penyidikan atau penuntut Umum menerbitkan penetapan penghentian penuntutan.

Perihal penetapan ini, di samping diatur dalam Pasal 12 di atas, juga diatur dalam Pasal 52 Ayat (5): (1) Dalam hal Proses Diversi berhasil mencapai kesepakatan, Hakim menyampaikan berita acara Diversi beserta kesepakatan Diversi kepada ketua pengadilan negeri untuk dibuat penetapan.

Demikian ketentuan mengenai Restorative Justice dalam UU SPPA yang dilakukan di luar 


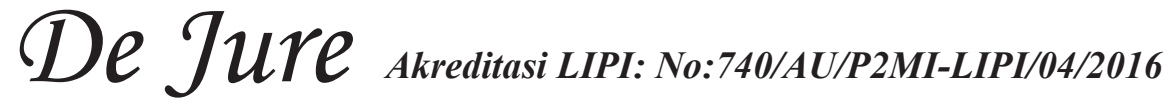

pengadilan/persidangan melalui mekanisme Diversi. Pada baian berikutnya akan diuraikan ketetuan mengenai Restorative Justice dalam UU SPPA yang dilakukan di dalam pengadilan/ persidangan melalui mekanisme non diversi/ mediasi.

\section{Restorative Justice di Dalam Pengadilan}

\section{a. Mekanisme Melalui Non Diversi/Mediasi}

Mekanisme penerapan Restorative Justice di dalam pengadilan tetap dimulai dengan upaya Diversi, yang dapat dilaksanakan di ruang mediasi pengadilan negeri. Kemudian ketika Diversi itu tidak berhasil mencapai kesepakatan, maka perkara dilanjutkan kepada tahap persidangan. Mekanisme demikian ini sebagaimana disebutkan dalam pasal 52 Ayat (1) sampai dengan Ayat (6). Berikut ketentuan pasal 25 Ayat (1) sampai dengan Ayat (6):

Bagian Keenam pemeriksaan di Sidang Pengadilan. Pasal 52.

Ketua pengadilan wajib menetapkan Hakim atau majelis hakim untuk menangani perkara Anak paling lama 3 (tiga) hari setelah menerima berkas perkara dari Penuntut Umum. (2) Hakim wajib mengupayakan Diversi paling lama 7 (tujuh) hari setelah ditetapkan oleh ketua pengadilan negeri sebagai Hakim; (3) Diversi sebagaimana dimaksud pada ayat (2) dilaksanakan paling lama 30 (tiga puluh) hari; (4) Proses Diversi dapat dilaksanakan di ruang mediasi pengadilan negeri; (5) Dalam hal proses Diversi berhasil mencapai kesepakatan Hakim menyampaikan berita acara Diversi beserta kesepakatan Diversi kepada ketua pengadilan negeri untuk dibuat penetapan; (6) Dalam hal Diversi tidak berhasil dilaksanakan, perkara dilanjutkan ke tahap persidangan.

Persidangan Anak dilakukan dalam ruang sidang khusus anak, dimana ruang tunggu anak dipisahkan dari ruang tunggu orang dewasa, serta waktu sidang anak juga didahulukan dari sidang orang dewasa. Hal ini sebagaimana diatur dalam pasal 53 Ayat (1) sampai dengan (3).Persidangan anak dinyatakan tertutup untuk umum, kecuali pembacaan putusan. Ketentuan ini disebutkan dalam pasal 54: "Hakim memeriksa perkara Anak dalam sidang yang dinyatakan tertutup umum, kecuali pembacaan putusan."

Di dalam sidang anak, hakim wajib memerintahkan orang tua/wali atau pendamping, Advokat atau pemberi bantuan hukum lainnya, dan Pembimbing Kemasyarakatan untuk mendampingi Anak. Akan tetapi, dalam hal orang tua/Wali dan/atau pendamping tidak hadir, sidang tetap dilanjutkan dengan didampingi Advokat atau pemberi bantuan hukum lainnya dan/ atau Pembimbing Kemasyarakatan. Ketentuan demikian wajib dilaksanakan oleh hakim, di mana ketika tidak dilaksanakan mengakibatkan sidang anak tersebut batal demi hukum. Ketentuan diatas, sebagaimana diatur dalam pasal 55 Ayat (1) sampai dengan (3).

\section{b. Bentuk Putusan}

Ketentuan mengenai putusan terhadap perkara anak yang berhadapan dengan hukum, disebutkan dalam Pasal 60 (mengenai penjatuhan putusan), Pasal 61 (mengenai pembacaan putusan), dan Pasal 62 (mengenai petikan/ salinan putusan). Mekanisme penjatuhan putusan, sebagaimana disebutkan dalam Pasal 60 adalah bahwa sebelum menjatuhkan putusan, Hakim memberikan kesempatan kepada orang tua/Wali dan/atau pendamping untuk mengemukakan hal yang bermanfaat bagi Anak. Dalam hal tertentu Anak Korban diberi kesempatan oleh Hakim untuk menyampaikan pendapat tentang perkara yang bersangkutan.

Dalam menjatuhkan putusan tersebut, Hakim wajib mempertimbangkan laporan penelitian kemasyarakatan dari Pembimbing Kemasyarakatan sebelum menjatuhkan putusan perkara. Pengabaian terhadap laporan penelitian kemasyarakatan, dimana tidak dijadikan pertimbangan dalam putusan Hakim, maka putusan tersebut batal demi hukum. Ketentuan demikian secara jelas tersebut dalam Pasal 60 Ayat (1) sampai dengan Ayat (4). Pembacaan putusan pengadilan dilakukan dalam sidang yang terbuka untuk umum dan dapat tidak dihadiri oleh Anak. Mengenai identitas Anak, Anak Korban, dan/atau Anak Saksi tetap harus dirahasiakan oleh media massa sebagaimana dimaksud dalam pasal 19 dengan hanya menggunakan inisial tanpa gambar.

Selengkapnya ketentuan dalam Pasal 61, berbunyi: (1) Pembacaaan putusan pengadilan dilakukan dalam sidang yang terbuka untuk umum dan dapat tidak dihadiri oleh Anak. (2) Identitas Anak, Anak Korban, dan/atau Anak Saksi tetap harus dirahasiakan oleh media massa sebagaimana dimaksud dalam Pasal 19 dengan hanya menggunakan inisial tanpa gambar. 
Perihal petikan putusan pengadilan wajib diberikan oleh pengadilan kepada anak atau Advokat atau pemberi bantuan hukum lainnya, Pembimbing Kemasyarakatan, dan Penuntut Umum pada hari putusan diucapkan. Salinan putusan pengadilan tersebut wajib diberikan oleh Pengadilan paling lama 5 (lima) hari sejak putusan diucapkan kepada Anak atau Advokat atau pemberi bantuan hukum lainnya, Pembimbing Kemasyarakatan, dan Penuntut Umum. Demikian ketentuan sebagaimana tersebut dalam Pasal 61 Ayat (1) dan (2), yang selengkapnya berbunyi: (1) Pengadilan wajib memberikan petikan putusan pengadilan wajib diberikan oleh pengadilan kepada anak atau Advokat atau pemberi bantuan hukum lainnya, Pembimbing Kemasyarakatan, dan Penuntut Umum. (2) Pengadilan wajib memberikan salinan putusan paling lama 5 (lima) hari sejak putusan diucapkan kepada Anak atau Advokat atau pemberi bantuan hukum lainnya, Pembimbing Kemasyarakatan, dan Penuntut Umum.

Demikian ketentuan mengenai putusan pengadilan terhadap perkara anak yang berhadapan dengan hukum. Putusan pengadilan tersebut memuat sanksi pidana berupa pidana atau tindakan. Perihal sanksi pidana terhadap anak yang berhadapan dengan hukum akan diuraikan dalam pembahasan dibawah ini.

\section{c. Sanksi Pidana}

Terkait dengan hukuman terhadap anak yang berhadapan dengan hukum, berdasarkan UU SPPA disebutkan ada dua macam, yaitu pidana atau tindakan. Ketentuan pidana dan tindakan disebutkan dalam Bab V UU SPPA Pasal 69: (1) Anak hanya dapat dijatuhi pidana atau dikenal tindakan berdasarkan ketentuan dalam UndangUndang ini. (2) Anak yang belum berusia 14 (empat belas) tahun hanya dapat dikenai tindakan.

Berdasarkan Pasal 69 di atas, hukuman terhadap anak yang berhadapan dengan hukum hanya ada dua macam, yaitu pidana dan tindakan. Mengenaitindakanini, terdapatbatasanbahwaanak yang belum berusia 14 (empat belas) tahun hanya dikenal tindakan.Ketentuan mengenai Restorative Justice tampak dalam Pasal 70, yang menyebutkan bahwa hakim dapat tidak menjatuhkan pidana atau pengenaan tindakan dengan berdasarkan pada pertimbangan segi keadilan dan kemanusiaan.
Pasal 70, Ringannya perbuatan keadaan pribadi Anak, atau keadaan pada waktu dilakukan perbuatan atau yang terjadi kemudian dapat dijadikan dasar pertimbangan hakim untuk tidak menjatuhka pidana atau mengenakan tindakan dengan mempertimbangkan segi kadilan dan kemanusiaan.Adapun ketentuan pidana dalam UU SPPA ini terdiri dari pidana pokok (Pasal 71 Ayat (1) dan pidana tambahan. (Pasal 71 Ayat (2). Pidana pokok bagi Anak terdiri atas: a. Pidana peringatan; $b$. Pidana dengan syarat: 1 ) pembinaan di luar lembaga; 2) pelayanan masyarakat; atau 3) pengawasan; c. Pelatihan kerja; d. Pembinaan dalam lembaga; dan e. Penjara. Sedangkan Pidana tambahan terdiri atas: a. Perampasan keuntungan yang diperoleh dari tindak pidana; atau $b$. Pemenuhan kewajiban adat.

Terdapat ketentuan khusus mengenai apabila dalam hukum materiil diancam pidana kumulatif berupa penjara dan denda, pidana denda diganti dengan pelatihan kerja. Ketentuan ini disebutkan dalam Pasal 71 Ayat (3) sebagai berikut: "apabila dalam hukum materiil diancam pidana kumulatif berupa penjara dan denda, pidana denda diganti dengan pelatihan kerja."

Terdapat larangan dalam penerapan ketentuan pidana yang dijatuhkan kepada Anak, yaitu pidana tersebut dilarang melanggar harkat dan martabat anak, sebagaimana disebabkan dalam Pasal 71 Ayat (4): "Pidana yang dijatuhkan kepada Anak dilarang melanggar harkat dan martabat Anak."

Kemudian terdapat ketentuan bahwa ketentuan lebih lanjut mengenai bentuk dan tata cara pelaksanaan pidana adalah diatur dengan Peraturan Pemerintah. Hal ini sebagaimana disebutkan dalam pasal 71 Ayat (5). Dalam Pasalpasal berikutnya: Pasal 72 dst dijelaskan mengenai jenis-jenis pidana yan telah disebutkan dalam pasal 71 di atas. Pasal 72 menjelaskan tentang pidana peringatan. Pasal 72 seacara jelas menegaskan bahwa: "Pidana peringatan merupakan pidana ringan yang tidak mengakibatkan pembatasan kebebasan anak."

Selanjutnya dalam pasal 74, Pasal 75 dijelaskan tentang pidana pembinaan. Dalam hal hakim memutuskan bahwa anak dibina di luar lembaga, lembaga tempat pendidikan dan pembinaan ditentukan dalam putusannya (Pasal 74). Pasal 75b menyebutkan: (1) Pidana pembinaan di luar lembaga dapat berupa keharusan: a. Mengikuti program pembimbingan 


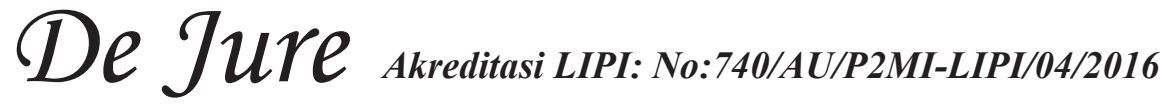

dan penyuluhan yang dilakukan oleh pejabat pembina; b. Mengikuti terapi di rumah sakit jiwa; atau c. Mengikuti terapi akibat penyalahgunaan alkohol, narkotika, psikotropika, dan zat adiktif lannya. (2) Jika selama pembinaan anak melanggar syarat khusus sebagaimana dimaksud dalam Pasal 73 ayat (4), pejabat pembina dapat mengusulkan kepada Hakim pengawas untuk memperpanjang masa pembinaan yang lamanya tidak melampaui maksimum 2 (dua) kali masa pembinaan yang belum dilaksanakan.

Kemudian Pasal 76 mengatur tentang pidana pelayanan masyarakat. (1) Pidana pelayanan masyarakat merupakan pidana yang dimaksudkan untuk mendidik Anak dengan meningkatkan kepeduliannya pada kegiatan kemasyarakatan yang positif. (2) Jika Anak tidak memenuhi seluruh atau sebgaian kewajiban dalam menjalankan pidana pelayanan masyarakat tanpa alasan yang sah, pejabat pembina dapat mengusulkan kepada Hakim pengawas untuk memerintahkan Anak tersebut mengulangi seluruh atau sebagian pidana pelayanan masyarakat yang dikenakan terhadapnya. (3) Pidana pelayanan masyarakat untuk Anak dijatuhkan paling singkat 7 (tujuh) jam dan paling lama 120 (seratus dua puluh) jam.

Selanjutnya dalam Pasal 77 diatur tentang pidana pengawasan: yang dapat dijatuhkan kepada Anak sebagaimana dimaksud dalam pasal 71 Ayat (1) Huruf b angka 3 paling singkat 3 (tiga) bulan dan paling lama 2 (dua) tahun. Dalam hal Anak dijatuhi pidana pengawasan tersebut. Anak ditempatkan di bawah pengawasan penuntut Umum dan dibimbing oleh Pembimbing Kemasyarakatan.

Adapun pidana pelatihan kerja dijelaskan dalam Pasal 78, yakni Pidana pelatihan kerja sebagaimana dimaksud dalam Pasal 71 ayat (1) Huruf c dilaksanakan di lembaga yang melaksanakan pelatihan kerja yang sesuai dengan usia Anak. Pidana pelatihan kerja tersebut dikenakan paling singkat 3 (tiga) bulan dan paling lama 1 (satu) tahun.

Berikutnya tentang pidana pembatasan kebebasan diatur dalam pasal 79: (1) Pidana pembatasan kebebasan diberlakukan dalam hal Anak melakukan tindak pidana berat atau tindak pidana yang disertai dengan kekerasan. (2) Pidana pembatasan kebebasan yang dijatuhkan terhadap Anak paling lama $1 / 2$ (satu per dua) dari maksimum pidana penjara yang diancamkan terhadap orang dewasa. (3) Minimum khusus pidana penjara tidak berlak terhadap Anak. (4) Ketentuan mengenai pidana penjara dalam KUHP berlaku juga terhadap Anak sepanjang tidak bertentangan dengan Undang-Undang ini.

Selanjutnya dalam Pasal 80 diatur tentang ketentuan mengenai pidana pembinaan di dalam lembaga. (1) Pidana pembinaan di dalam lembaga dilkaukan di tempat pelatihan kerja atau lembaga pembinaan yang diselenggarakan, baik oleh pemerintah maupun swasta; (2) Pidana pembinaan di dalam lembaga dijatuhkan apabila keadaan dan perbuatan Anak tidak membahayakan masyarakat; (3) Pembinaan dalam lembaga dilaksanakan paling singkat 3 (tiga) bulan dan paling lama 24 (dua puluh empat) bulan; (4) Anak yang telah menjalani $1 / 2$ (satu perdua) dari lamanya pembinaan di dalam lembaga dan tidak kurang dari 3 (tiga) bulan berkelakuan baik berhak mendapatkan pembebasan bersyarat.

Selanjutnya dalam Pasal 81 diatur tentang pidana penjara di LPKA. Pidana penjara di LPKA ini diperuntukan bagi anak yang apabila keadaan dan perbuatannya akan membahayakan, Pasal 81: (1) Anak dijatuhi pidana penjara di LPKA apabila keadaan dan perbuatan Anak akan membahayakan masyarakat; (2) Pidana penjara yang dapat dijatuhkan kepada Anak paling lama 1/2 (satu per dua) dari maksimum ancaman pidana penjara bagi orang dewasa; (3) Pembinaan di LPKA dilaksanakan sampai Anak berumur 18 (delapan belas) tahun; (4) Anak yang telah menjalani 1/2 (satu per dua) dari lamanya pembinaan di LPKA dan berkelakuan baik berhak mendapatkan pembebasan bersyarat.

Penerapan pidana penjara terhadap anak hanyalah digunakan sebagai upaya terakhir. Ketentuan ini jelas memberikan perlindungan hak-hak anak, dengan mengedepankan pendekatan Restorative Justice. Ketentuan tersebut secara jelas disebutkan dalam Pasal 81 Ayat (5), yang berbunyi: (1) Pidana penjara terhadap Anak hanya digunakan sebagai upaya terakhir.

Demikian juga dalam hukuman pidana terhadap anak tidak ada hukuman mati atau hukuman penjara seumur hidup. Hukuman penjara maksimal hanya 10 (sepuluh) tahun. Ketentuan ini secara jelas tersebut dalam Pasal 81 Ayat (6):Jika tindak pidana yang dilakukan Anak merupakan tindak pidana yang diancam dengan pidana mati atau tindak pidana penjara seumur hidup, pidana 
yang dijatuhkan adalah pidana penjara paling lama 10 (sepuluh) tahun.

Ketentuan khusus mengenai tindakan disebutkan dalam Pasal 82 sampai dengan Pasal 83. Menurut Pasal 82 tindakan yang dapat dikenakan kepada anak meliputi: a. Pengembalian kepada orang tua/wali; b. Penyerahan kepada seseorang; c. Perawatan di rumah sakit jiwa; d. Perawatan di LPKS; e. Kewajiban mengikuti pendidikan formal dan/atau pelatihan yang diadakan oleh pemerintah atau badan swasta; f. Pencabutan surat izin mengemudi; dan/atau g. Perbaikan akibat tindak pidana. Khusus tindakan berupa pencabutan surat izin mengemudi dilakukan paling lama 1 (satu) tahun. Secara terperinci ketentuan mengenai tindakan akan diatur dalam Peraturan Pemerintah.

Pasal 82 Ayat (1) sampai dengan Ayat (4): (1) Tindakan yang dapat dikenakan kepada Anak meliputi: a. Pengembalian kepada orang tua/wali; b. Penyerahan kepada seseorang; c. Perawatan di rumah sakit jiwa; d. Perawatan di LPKS; e. Kewajiban mengikuti pendidikan formal dan/atau pelatihan yang diadakan oleh pemerintah atau badan swasta; f. Pencabutan surat izin mengemudi; dan/atau g. Perbaikan akibat tindak pidana. (2) Tindakan sebagaimana dimaksud pada ayat (1) huruf $d$, huruf e, dan huruf $f$ dikenakan paling lama 1 (satu) tahun. (3) Tindakan sebagaimana dimaksud pada ayat (1) dapat diajukan oleh Penuntut Umum dalam tuntutnnya, kecuali tindak pidana diancam dengan pidana penjara paling singkat 7 (tujuh) tahun. (4) Ketentuan lebih lanjut mengenai tindakan sebagaimana dimaksud pada ayat (1) diatur dengan Peraturan Pemerintah

\section{KESIMPULAN}

Apa latar belakang filosofis lahirnya Restorative Justice dan implemetasinya dalam SPPA adalah pandangan hidup bangsa Indonesia dalam berbangsa dan bernegara, yaitu Pancasila, yang dijabarkan ke dalam pencerminan keadilan, ketertiban, dan kesejahteraan yang diinginkan masyarakat Indonesia, yang mengharuskan perlindungananakdanhak-haknya, sebagaiamanah dan karunia Tuhan yang Maha Esa yang memiliki harkat dan martabat sebagai manusia seutuhnya. Untuk perlindungan hukum itu diperlukan perlindungan khusus yang diwujudkan dalam UU No. 11 Tahun 2012 tentang Sistem Peradilan Pidana
Anak, yang mewajibkan penerapan Restoratif Justice, agar dapat terwujud peradilan yang benarbenar menjamin perlindungan kepentingan terbaik terhadap anak yang berhadapan dengan hukum sebagai penerus bangsa.

Mengapa Restorative Justice harus dilakukan sebagai perlindungan terhadap anak yang berhadapan dengan hukum, karena pada dasarnya anak tersebut tidak dapat dilepaskan dari konteks yang melingkupinya, yaitu keluarga, lingkungan, dan faktor-faktor yang berpengaruh terhadap dirinya, termasuk faktor ekonomi. Oleh karenanya, menjadi tidak adil apabila anak yang berkonflik dengan hukum itu dokenai sanksi pembalasan (retributif) atas pelanggaran hukum yang dilakukannya, tanpa memperhatikan keberadaannya dan kondisi yang melingkupi dirinya.

Bagaimana cara menerapkan Restorative Justice dalam praktik peradilan pidana sebagai perlindungan anak yang berhadapan dengan hukum, dilakukan melalui mekanisme diversi, dengan produk pengadilan berupa penetapan (Pasal putusan, yaitu pidana atau tindakan (Pasal 12 dan 52), dan non diversi/mediasi, yang bisa dilakukan di luar atau di dalam persidangan dengan produk pengadilan berupa putusan, yaitu pidana atau tindakan (pasal 69). Meknisme dialog dan mediasi tersebut, yang merupakan perwujudan prinsip musyawarah mufakat, dilangsungkan dengan melibatkan selain kedua belah pihak pelaku dan korban juga dapat melibatkan pihak lain (Pemerintah, Ketua Adat/Masyarakat dan Pemuka Agama). Sungguhpun demikian, ketentuan diversi dalam UU SPPA mengandung titik lemah, karena diskriminatif, yakni hanya diberlakukan terhadap tindak pidana yang dilakukan anak yang bermasalah dengan hukum yang ancaman hukumannya dibawah 7 (Tujuh) tahun. Dalam praktek peradilan pidana, penerapan Restorative Justice sebagai wujud perlindungan hak anak yang berhadapan dengan hukum belum menjadi kecenderungan utama. Oleh karena itu, untuk mendukung keberhasilan penerapan Restorative Justice, refungsionalisasi hukum adat menjadi penting dilakukan, sebagai bentuk pluralisme hukum, yang merupakan suatu keniscayaan, dan sejalan dengan prinsip kebinekaan. 


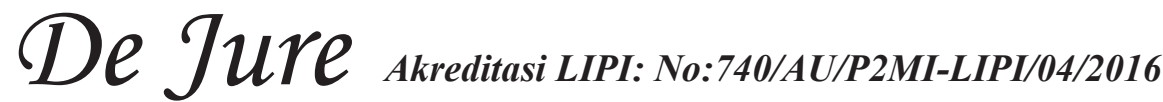

\section{SARAN}

Penerapan pendekatan Restorative Justice dalam menangani perkara anak yang berhadapan dengan hukum, dan masih menunggu Peraturan Pemerintah (PP) sebagai peraturan pelaksanaannya, para penegak hukum, baik polisi, jaksa, dan hakim harus mempunyai budaya hukum progresif, yakni menerapkan pendekatan Restorative Justice tersebut sebagai pendekatan utama dalam penyelesaian perkara anak yang berhadapan dengan hukum, bukannya manusia untuk hukum.

Pemerintah harus segera membuat PP, yang menekankan bahwa penerapan Restorative Justice terhadap anak yang berhadapan dengan hukum, tidak perlu dilakukan pembedaan-pembedaan persyaratan sebagaimana yang diatur dalam UU SPPA, dan sebaliknya terhadap semua anak yang berhadapan dengan hukum dapat diperlakukan Restorative Justice dengan segala muatan yang ada di dalamnya tanpa membedakan ancaman pidana serta jenis pidana yang dilakukan.

Perlu dilakukan penelitian lebih lanjut, yang menganalisis putusan-putusan pengadilan yang dapat dikategorikan sebagai putusan yang menggunakan pendekatan Restorative Justice sebagai pendekatan utama. 


\section{DAFTAR KEPUSTAKAAN}

\section{Buku}

Eva Achjani Zulfa, Pergeseran Paradigma Pemidanaan, Bandung: Lubuk Agung, 2011.

Djaniko MH. Girsang, Persepktif Restorative Justice Sebagai Wujud Perlindungan Hak Anak Yang Berkonflik Dengan Hukum, Universitas Jayabaya, 2014.

I Made Sepud, "Perlindungan Hukum Terhadap Anak yang Berhadapan Dengan Hukum Melalui Diversi Dalam sistem Peradilan Pidana Anak", Penerbit: CV. R.A. De. Rozarie, Surabaya, 2013.

Muhammad Joni, Penjara (Bukan Tempat Anak) (Jakarta: Perhimpunan Advokasi Anak Indonesia), 2012.

Musakkir, "Penerapan Prinsip Keadilan Restoratif Terhadap Penyelesaian Perkara Pidana dalam Perspektif Sosiologi Hukum", Orasi Penerimaan Jabatan Guru Besar Tetap dalam Ilmu Sosiologi Hukum, Fakultas Hukum Universitas Hasanuddin, Makasar, 12 Juli 2009.

Muladi dan Suharyono AR, "Kapita Selekta Huku Pidana, Badan Penerbitan Universitas Diponegoro Semarang, 1999, hlm 127-129, dan Suhariyono AR, Pembaruan Pidana Denda di Indonesia: Pidana denda sebagai Sanksi Alternatif, Papas Sinar Sinanti, Jakarta, 2012, hlm. 295.

Nashrina, Perlindungan Hukum Pidana Bagi Anak di Indonesia, Jakarta: Rajawali Press, 2011.

Jurnal, Majalah. Koran, Internet

Http:// Ananda Rizvietha. Wordpress. com/2012/11/27/sistem-hukum-acarapidana/.

Artidjo Alkostar, Restorative Justice, dalam Varia Peradilan: Majalah Hukum, Tahun XXII, No. 262 (September), 2007.

\section{Peraturan Perundang-undangan}

Staatsblad No. 732 Tahun 1915 tentang Wetboek van Strafrecht (WvS) Kitab Undang-Undang Hukum Pidana (KUHP).
Undang-Undang Nomor 8 Tahun 1981 tentang Kitab Undang-Undang Hukum Acara Pidana (KUHAP) (LN RI Rahun 1981 No. 76 TLN RI No. 3258).

Undang-Undang Nomor 4 Tahun 1979 tentang Kesejahteraan Anak (LN RI Tahun No. 32, TLN RI No. 3143).

Undang-Undang Nomor 39 Tahun 1999 tentang Hak Asasi Manusia (LN RI Tahun 1999 No. 165, TLN RI No. 3886).

Undang-Undang Nomor 35 Tahun 2014 tentang Perubahan Atas UU Nomor 23 Tahun 2002 Tentang Perlindungan Anak.

Undang-Undang RI No, 11 Tahun 2005 Tentang pengesahan International Covenan ov Social, Economic and Cultural Rights (Kovenan Internasional Tentang Hak-Hak Ekonomi, Sosial, dan Budaya) (LN RI Tahun 2005 No. 118 TLN RI No. 4557).

Undang-Undang Nomor 11 Tahun 2012 tentang Sistem Peradilan Pidana Anak (LN RI Tahun 2012No. 153, TLN No. 5332). 


\section{De JuYe akreditasi LIPI: No:740/AU/P2MI-LIPI/04/2016}

\section{BIODATA PENULIS}

Nama, Drs. Ulang Mangun Sosiawan, M.H., lahir di Tegal, pada tanggal 27 Juli 1962. Adalah Sarjana Ekonomi Alumni Fakultas Ekonomi Universitas Krisnadwipayana Jakarta, menyandang gelar akademik Magister Hukum bidang Ilmu Hukum (MH) dari Sekolah Tinggi Ilmu Hukum "Institut Business Law and Administration Management (IBLAM).Awal karier sebagai Pegawai Negeri Sipil di mulai pada Maret 1983 di Pusat Pembinaan Sistem dan Pranata Hukum Nasional (PUSBINSIS) BPHN. Saat ini sebagai Pejabat Fungsional Peneliti Utama di BALITBANG HUKUM DAN HAM, KEMENKUMHAM RI.Pada tahun 20092014 S/D 2015-2020 terpilih sebagai Pengurus Koperasi Pengayoman Pegawai Kementerian Hukum dan HAM sebagai Wakil Ketua Umum KPPDK Pusat. 


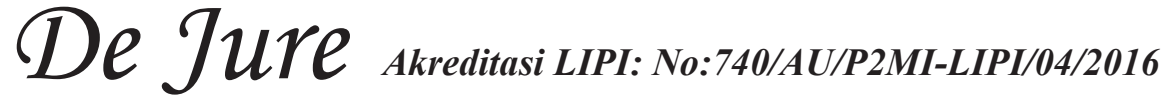

\section{PEDOMAN PENULISAN NASKAH JURNAL PENELITIAN HUKUM DE JURE}

1. Naskah yang dimuat dalam Jurnal Penelitian Hukum De Jure adalah tulisan yang belum pernah dipublikasikan dalam media massa.

2. Naskah yang dimuat dalam Jurnal Penelitian Hukum De Jure meliputi tulisan tentang hasil penelitian (penelitian empiris maupun penelitian normatif atau studi dokumenter), pemikiran dan informasi lain yang bersifat ilmiah.

3. Menggunakan bahasa Indonesia yang baku.

4. Sistimatika Penulisan :

A. Naskah artikel hasil penelitian empiris :

o Judul aktual

Menggambarkan isi naskah dan maksimal 14 kata ditulis dalam bahasa Indonesia dan Inggris

o Nama penulis

Tanpa gelar akademik, jabatan, kepangkatan, alamat lembaga/instansi dan e-mail

o Abstrak

Berisi Latar Belakang, Rumusan Masalah, Tujuan, Kegunaan, Metode, Isi

Pembahasan, Analisis, Kesimpulan dan Saran Temuan ditulis dalam satu spasi;

150 kata (10-20 baris/ satu (1) paragraf) diketik menggunakan huruf Times New

Roman; font 11 italic; ditulis dalam bahasa Indonesia dan bahasa Inggris.

o Kata Kunci

Mengandung yang di indekskan ditulis dalam bahasa Indonesia dan Inggris

dengan minimal 3 kata maksimal 5 kata

- PENDAHULUAN

Berisi latar belakang masalah dan rumusan masalah, tujuan, kegunaan, kerangka Teori/Konsep, Metode (metode penelitian yang digunakan, di antaranya meliputi jenis penelitian, lokasi penelitian, sumber data, teknik pengumpulan data, pengolahan data dan analisis data.)

- PEMBAHASAN

Berisi, pembahasan terhadap masalah yang diteliti

- Analisis

Berisi analisis dari semua pokok pembahasan

- PENUTUP

Kesimpulan dan saran

Kesimpulan dan saran ditulis dalam bentuk uraian bukan dalam bentuk'angka

- DAFTAR KEPUSTAKAAN

Daftar Pustaka : ditulis berdasarkan abjad, dengan urutan : Nama pengarang. Judul buku. Kota penerbit: nama penerbit, tahun penerbitan.

Contoh ....Hamzah. Andi, Bantuan Hukum suatu Tinjauan Yuridis. Ghalia

Indonesia, Jakarta, 1983. 


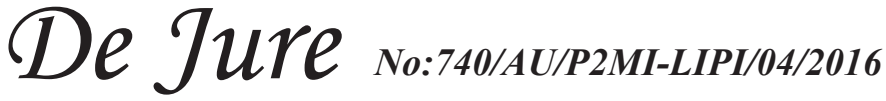

B. Naskah artikel ulasan Hasil penelitian normatif atau studi dokumenter), pemikiran dan informasi lain yang bersifat ilmiah.

o Judul aktual

Menggambarkan isi naskah dan maksimal 14 kata ditulis dalam bahasa

Indonesia dan Inggris

o Nama penulis

Tanpa gelar akademik, jabatan, kepangkatan, alamat lembaga/instansi dan e-mail

o Abstrak

Berisi Latar Belakang, Rumusan Masalah, Tujuan, Kegunaan, Metode, Isi

Pembahasan, Analisis, Kesimpulan dan Saran Temuan ditulis dalam satu spasi;

150 kata (10-30 baris/ satu (1) paragraf) diketik menggunakan huruf Times

New Roman; font 11 italic; ditulis dalam bahasa Indonesia dan bahasa Inggris

o Kata Kunci

Mengandung yang di indekskan ditulis dalam bahasa Indonesia dan Inggris

minimal 3 kata maksimal 5 kata

- PENDAHULUAN

Latar belakang masalah dan rumusan masalah

- PEMBAHASAN

Berisi, pembahasan terhadap masalah yang dikaji

- ANALISIS

Berisi analisis dari semua pokok pembahasan

- PENUTUP

Kesimpulan Dan Saran

Kesimpulan dan saran ditulis dalam bentuk uraian bukan dalam bentuk angka

- DAFTAR KEPUSTAKAAN

Daftar Pustaka : ditulis berdasarkan abjad, dengan urutan : Nama pengarang. Judul buku. Kota penerbit : nama penerbit, tahun penerbitan.

Contoh ....Hamzah. Andi, Bantuan Hukum suatu Tinjauan Yuridis. Ghalia

Indonesia, Jakarta, 1983.

5. Naskah dilengkapi dengan indeks.

6. Naskah diketik rapi 1,5 spasi di atas kertas A4; menggunakan huruf Times New Roman; Font 11; antara 20-30 halaman; diprint out dan disertai soft copy CD.

7. Penulisan kutipan sumber rujukan dengan sistem bodynote, yaitu menulisk ${ }^{\wedge} \mathrm{n}$ nama pengarang (tanpa gelar akademik); tahun penerbitan dan no halaman, yang ditulis dalam kurung; diletakan dibelakang kutipan. Contoh : .(Hamzah, 2007: 15)

8. Isi tulisan di luar tanggungjawab redaksi. Dan redaksi berhak mengedit redaksional tanpa merubah arti.

9. Naskah yang belum memenuhi syarat akan dikonfirmasikan atau dikembalikan untuk diperbaiki.

10. Keterangan lengkap dapat menghubungi redaksi Jurnal Peneltian Hukum De Jure melalui Email: jurnaldejure@yahoo.com 
